\title{
RENDEMEN DAN KARAKTERISTIK KIMIA FISIK BIODIESEL DARI TRANSESTERIFIKASI MINYAK BIJI KAPUK TEROZONASI DENGAN BANTUAN GELOMBANG ULTRASONIK
}

\author{
HARYONO \\ Departemen Kimia, FMIPA, Universitas Padjadjaran \\ Jl. Raya Bandung-Sumedang Km.21 Jatinangor 45363, Sumedang, Jawa Barat \\ *email : haryono@unpad.ac.id
}

\begin{abstract}
Abstrak. Biodiesel merupakan bahan bakar alternatif ramah lingkungan dan bersifat terbarukan. Biodiesel secara substansi kimia merupakan metil atau etil ester dari asam lemak rantai panjang sehingga dapat disintesis dari berbagai jenis sumber asam lemak hayati. Minyak biji kapuk adalah salah satu sumber asam lemak hayati potensial karena umumnya memiliki kadar asam lemak bebas tinggi sehingga terkelompok sebagai minyak non pangan. Sintesis biodiesel dapat dilakukan dengan berbagai modifikasi metode, salah satunya dengan memanfaatkan ozon sebagai agen pengoksidasi untuk menyederhanakan struktur molekul trigliserida dari minyak, dan melibatkan pemakaian gelombang ultrasonik untuk membantu proses pencampuran antar bahan. Tujuan dari penelitian ini adalah mempelajari pengaruh tahap ozonasi dan lama waktu transesterifikasi dengan bantuan gelombang ultrasonik terhadap karakteristik biodiesel yang dihasilkan dari minyak biji kapuk. Hasil penelitian menunjukkan bahwa ozonasi terhadap minyak biji kapuk selama 120 menit telah berhasil menyederhanakan struktur molekul trigliserida dari minyak. Transesterifikasi selama 180 menit terhadap minyak biji kapuk dengan bantuan gelombang ultrasonik pada frekuensi $25 \mathrm{kHz}$ menghasilkan rendemen biodiesel tertinggi. Biodiesel yang dihasilkan dari semua variasi lama waktu transesterifikasi telah memenuhi Standar Biodiesel berdasarkan parameter bilangan asam, titik nyala, dan densitas. Namun beradasarkan parameter viskositas belum memenuhi syarat.
\end{abstract}

Kata kunci: biodiesel, minyak biji kapuk, ozon, transesterifikasi, ultrasonik

\begin{abstract}
Biodiesel is an alternative fuel that is environmentally friendly and renewable. Biodiesel chemically is a methyl or ethyl ester of long chain fatty acids so that it can be synthesized from various types of biological fatty acid sources. Kapok seed oil is a potential source of biological fatty acids because it generally has high levels of free fatty acids so that it is classified as a non-food oil. Biodiesel synthesis can be carried out with various modification methods, one of which is by utilizing ozone as an oxidizing agent to simplify the triglyceride molecular structure of the oil, and involving the use of ultrasonic waves to assist the mixing process between ingredients. The purpose of this study was to study the effect of the ozonation stage and the duration of transesterification using ultrasonic waves on the characteristics of biodiesel produced from kapok seed oil. The results showed that ozonation of kapok seed oil for 120 minutes had succeeded in simplifying the triglyceride molecular structure of the oil. Transesterification for 180 minutes of kapok seed oil with the help of ultrasonic waves at a frequency of $25 \mathrm{kHz}$ resulted in the highest biodiesel yield. The biodiesel produced from all variations of the transesterification time has met the Biodiesel Standard based on the parameters of acid number, flash point, and density. However, based on the viscosity parameters it has not met the requirements.
\end{abstract}

Keywords: biodiesel, kapok seed oil, ozone, transesterification, ultrasonic 


\section{Pendahuluan}

Biodiesel sebagai bahan bakar alternatif yang setara dengan minyak diesel, secara substansi kimia merupakan metil atau etil ester dari asam lemak rantai panjang. Asam lemak rantai panjang banyak ditemukan pada berbagai jenis minyak nabati dan lemak hewan. Oleh karena itu biodiesel dapat disintesis dari minyak nabati, lemak hewan, atau sumber-sumber asam lemak lainnya seperti limbah minyak goreng $[1,2]$. Salah satu jenis minyak nabati sebagai bahan baku potensial pada sintesis biodiesel adalah minyak biji kapuk (Ceiba pentandra). Kandungan minyak pada biji kapuk sekitar 27-32\%, tergantung varietas tanaman dan kondisi tanah maupun cuaca [3, 4]. Minyak biji kapuk merupakan minyak non pangan sehingga sangat menguntungkan sebagai bahan baku pada pembuatan biodiesel karena tidak bersaing dengan minyak pangan. Selain itu, pemakaian minyak pangan pada pembuatan biodiesel cenderung meningkatkan biaya produksi [5].

Komposisi asam lemak dan sifat kimia-fisik dari minyak biji kapuk bervariasi. Haryono dan Marliani melaporkan bahwa pada minyak biji kapuk terdapat asam lemak tak jenuh sekitar 63,27\% [6]. Studi lainnya menyatakan minyak biji kapuk tersusun dari $41,37 \%$ asam lemak tak jenuh dan $40,8 \%$ asam lemak jenuh dengan bilangan penyabunan sebesar $152,79 \mathrm{mg} \mathrm{KOH} / \mathrm{g}$ minyak dan bilangan iodine $129,79 \mathrm{mg} \mathrm{I}_{2} / 100 \mathrm{~g}$ minyak [4]. Hal ini menyebabkan minyak biji kapuk mudah tengik, sehingga kurang baik untuk dikembangkan sebagai minyak pangan. Pemanfaatan minyak biji kapuk, minyak nabati yang didominasi oleh asam lemak tak jenuh rantai panjang, sebagai bahan baku pada pembuatan biodiesel akan cenderung menurunkan bilangan cetana dan meningkatkan viskositas dari biodiesel yang dihasilkan, serta dapat memicu reaksi polimerisasi pada saat pembakaran $[7$, 8].

Upaya penurunan derajat ketidakjenuhan dan penyederhanaan rantai karbon pada asam lemak minyak biji kapuk dapat dilakukan dengan ozonasi. Ozonasi telah terbukti menurunkan derajat ketidakjenuhan pada minyak kedelai dan minyak zaitun [9]. Salah satu produk dari ozonasi terhadap minyak nabati adalah asam lemak bebas. Asam lemak bebas yang terbentuk dari ozonasi minyak nabati, misalnya minyak biji kapuk, selanjutnya dapat dikonversi menjadi biodiesel dengan reaksi esterifikasi [2].

Istilah Ultrasonik mengacu pada gelombang suara yang berada di atas frekuensi pendengaran manusia, yaitu sekitar $20 \mathrm{kHz}$ (kilohertz), atau 20.000 siklus per detik. Jenis gelombang suara yang bergetar cepat ini mentransfer energi ke dalam cairan dan menciptakan getaran hebat, yang membentuk gelembung "kavitasi" saat bagian suara bertekanan rendah melewati cairan. Setelah gelombang berlalu, gelembunggelembung itu pecah, menyebabkan kontraksi tiba-tiba pada cairan sehingga menghasilkan pencampuran yang sangat intens di area gelembung tersebut [10]. Pencampuran intens tersebut dapat dimanfaatkan untuk berbagai keperluan, salah satunya untuk pengontakan antar materi reaktan maupun katalis pada sintesis biodiesel.

Biodiesel secara konvensional disintesis melalui tahap esterifikasi dan transesterifikasi katalitik dengan bantuan pemanasan dan pengadukan. Tahap esterifikasi menggunakan katalis asam sulfat, sedangkan pada trans-esterifikasi digunakan katalis potassium atau sodium hidroksida. Pada prakteknya, metode sintesis biodiesel secara konvensional tersebut membutuhkan waktu pereaksian relatif lama, yaitu 1-2 jam $[2,11]$ dan energi relatif besar. Kebutuhan waktu pada tahap 
esterifikasi maupun tran-esterifikasi dalam sintesis biodiesel secara konvensional tersebut dapat direduksi dengan memanfaatkan bantuan gelombang ultrasonik [12].

Tujuan penelitian ini adalah mempelajari pengaruh penggunaan gelombang ultrasonik dan ozon terhadap rendemen dan sifat kimia fisik dari biodiesel yang disintesis dari minyak biji kapuk.

\section{Metode Penelitian}

\subsection{Penghilangan gum dari minyak biji kapuk}

Sejumlah tertentu minyak biji kapuk (dari daerah Terboyo, Semarang, Jawa Tengah) dipanaskan pada suhu $70{ }^{\circ} \mathrm{C}$ dan diaduk selama 15 menit, kemudian ditambahkan larutan asam fosfat $85 \%$ (BrataChem) sebanyak 0,1\% terhadap berat minyak, dan diaduk selama 5 menit. Selanjutnya akuades sebanyak $20 \%$ dari berat minyak ditambahkan dan diaduk selama 5 menit.

Campuran hasil penghilangan gum (getah) didinginkan sampai suhu ruang. Campuran kemudian disentrifugasi pada kecepatan 3500 rpm selama 25 menit, lalu disaring untuk memisahkan gum dari minyak. Minyak biji kapuk dari tahap penghilangan gum selanjutnya dianalisis sifat kimia fisiknya (bilangan asam, bilangan penyabunan, densitas, dan viskositas) dan komposisi asam lemaknya dengan instrumen KG-SM, Kromatografi Gas-Spektroskopi Massa (Shimadzu QP 2010 ULTRA).

\subsection{Penyederhanaan struktur molekul minyak biji kapuk dengan ozon}

Minyak biji kapuk dari tahap penghilangan gum dimasukkan ke dalam bejana ozonasi yang dilengkapi pengaduk. Saluran pengaliran ozon dihubungkan dari ozone generator (Ozone S2Q-OZ/2) ke bagian dasar dari bejana ozonasi. Oksidasi terhadap minyak dilakukan dengan mengoperasikan ozone generator yang mampu mengubah oksigen dalam udara menjadi ozon dengan kapasitas laju alir 7,56 L/menit selama 120 menit, dan dibantu dengan reagen pengoksidasi hidrogen peroksida (Merck) sebanyak $0,1 \%$.

Ozon berkontak dengan minyak biji kapuk selama ozonasi dengan cara digelembungkan pada bagian dasar bejana ozonasi. Minyak biji kapuk dari tahap ozonasi kemudian dianalisis sifat kimia-fisiknya (bilangan asam, bilangan penyabunan, densitas, dan viskositas) dan komposisi asam lemaknya dengan instrumen KG-SM.

\subsection{Esterifikasi dan Transesterifikasi Minyak Biji Kapuk Teroksidasi Ozon}

Minyak biji kapuk dari tahap ozonasi selanjutnya diesterifikasi dengan bantuan gelombang ultrasonik untuk mengkonversi asam lemak bebas dari minyak menjadi metil ester (biodiesel). Minyak biji kapuk dan metanol dengan rasio mol 1:6 dimasukkan ke dalam bejana reaktor yang telah dilengkapi ultrasonic generator. $\mathrm{H}_{2} \mathrm{SO}_{4} 98 \%$ (Merck) sebanyak 1\% (v/v) dicampurkan dengan minyak sebagai katalis. Campuran reaktan dan katalis direaksikan pada suhu $60{ }^{\circ} \mathrm{C}$ selama 30 menit. Sebelum diselenggarakan esterifikasi tersebut, dilakukan pencampuran terlebih dahulu antara minyak, metanol, dan katalis dengan bantuan ultrasonik pada frekuensi $35 \mathrm{kHz}$ [13]. Fase minyak dari esterifikasi kemudian dipisahkan dari fase gliserol dengan pengendapan di dalam corong pisah. Fase minyak dimurnikan dari 
sisa metanol dan katalis dengan distilasi pada suhu didih metanol, pencucian dengan aquades, dan pengeringan.

Fase minyak dari esterifikasi setelah dimurnikan selanjutnya dikonversi lanjut menjadi biodiesel melalui tahap transesterifikasi. Fase minyak dari esterifikasi dipanaskan pada suhu $100{ }^{\circ} \mathrm{C}$ di dalam reaktor, kemudian metanol (pure grade, Merck) dengan rasio mol minyak terhadap metanol 1:12 dan kalsium oksida (pure grade, Merck) sebagai katalis sebanyak 3\% dimasukkan ke dalam reaktor tersebut. Fase minyak, metanol, dan katalis dicampurkan dengan bantuan gelombang ultrasonik $35 \mathrm{kHz}$ selama 30 detik. Hasil pencampuran direaksikan pada suhu 60 ${ }^{\circ} \mathrm{C}$ dengan waktu reaksi divariasiakan pada 90, 120, dan 180 menit. Selanjutnya, campuran hasil reaksi disaring dengan penyaring buchner untuk memisahkan katalis kalsium oksida sisa. Biodiesel di dalam campuran filtrat selanjutnya dimurnikan dengan pengendapan fase gliserol dan distilasi metanol. Biodiesel dari tahap transesterifikasi pada setiap variasi waktu reaksi ditentukan rendemennya dan dikarakterisasi sifak kimia fisiknya (bilangan asam, bilangan penyabunan, titik nyala, densitas, dan viskositas kinematik). Biodiesel dari waktu reaksi optimum kemudian dianalisis komposisi metil esterya dengan instrumen KG-SM. Rendemen biodiesel dihitung berdasarkan Persamaan (1).

Rendemen biodiesel $=\frac{\mathrm{W}_{\text {Biodiesel }}}{\mathrm{W}_{\text {Minyak biji kapuk }}} \times 100 \%$

Dengan: $\mathrm{W}_{\text {Biodiesel }}$ dan $\mathrm{W}_{\text {Minyak biji kapuk }}=$ berat biodiesel murni dan minyak biji kapuk.

\section{Hasil dan Pembahasan}

\subsection{Karakteristik kimia fisik minyak biji kapuk dari tahap penghilangan gum}

Gum atau getah pada minyak nabati secara substansi kimia adalah senyawa fosfatida dan fosfolipid. Beberapa jenis gum, khususnya garam kalsium dan magnesium dari gum, merupakan pengemulsi kuat. Oleh karena itu, jika pada sintesis biodiesel terbentuk sabun, sabun akan sulit dipisahkan dari biodiesel. Selain itu, kandungan gum di dalam produk biodiesel dapat menyebabkan terbentuknya endapan yang tidak diinginkan pada biodiesel yang berpotensi tertimbun membentuk kerak di ruang bakar dan saluran bahan bakar [2].

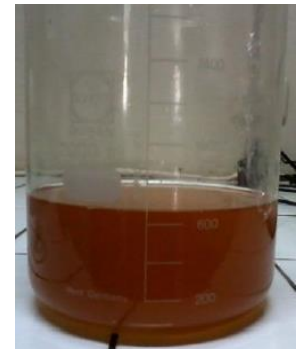

(a)

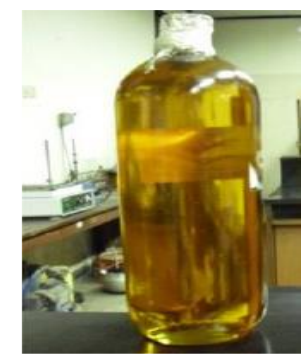

(b)

Gambar 1. Penampilan Fisik dari Minyak Biji Kapuk: (a) Sebelum dan (b) Setelah Tahap Penghilangan Gum

Dari hasil pengamatan, minyak kapuk dari tahap penghilangan getah memiliki warna kuning cerah dan tidak lagi dijumpai endapan berwarna putih. Pada minyak sebelum penghilangan getah, minyak berwarna lebih gelap. Perbedaan penampilan 
fisik dari minyak biji kapuk antara sebelum dan sesudah tahap penghilangan gum ditampilkan pada Gambar 1.

Hasil karakterisasi sifat kimia fisik dan komposisi asam lemak terhadap minyak biji kapuk setelah tahap penghilangan gum secara berturut-turut ditampilkan pada Tabel 1 dan Tabel 2. Data pada Tabel 1 menunjukkan bahwa bilangan penyabunan dari minyak biji kapuk bernilai relatif rendah, sedangkan nilai viskositasnya relatif tinggi. Pada minyak dan lemak terdapat kecenderungan dengan semakin rendahnya bilangan penyabunan, massa molar dari minyak dan lemak tersebut akan semakin tinggi. Sedangkan semakin tingginya massa molar dari minyak dan lemak mengindikasikan bahwa minyak dan lemak tersebut tersusun dari trigliserida dengan didominasi oleh asam lemak rantai panjang. Dengan demikian, pada minyak biji kapuk terdapat lebih banyak asam lemak rantai panjang pada struktur trigliseridanya. Jenis asam lemak rantai panjang akan menyebabkan gaya gesek antar molekul semakin kuat dan intensif. Selain itu, asam lemak rantai panjang menyebabkan gaya gesek internal antar molekul asam lemak semakin kuat dan intensif sehingga viskositas dari minyak biji kapuk cenderung tinggi [14].

Tabel 1. Sifat Kimia Fisik Minyak Biji Kapuk Setelah Tahap Penghilangan Gum

\begin{tabular}{ll}
\hline Parameter (Satuan) & Nilai \\
\hline Bilangan asam $(\mathrm{mg} \mathrm{KOH} / \mathrm{g})$ & 17,11 \\
Bilangan penyabunan $(\mathrm{mg} \mathrm{KOH} / \mathrm{g})$ & 78,84 \\
Densitas pada $40^{\circ} \mathrm{C}\left(\mathrm{kg} / \mathrm{m}^{3}\right)$ & 907,5 \\
Viskositas pada $40^{\circ} \mathrm{C}\left(\mathrm{mm}^{2} / \mathrm{s}\right)$ & 30,09 \\
\hline
\end{tabular}

Hasil karakterisasi sifat kimia fisik dari minyak biji kapuk tersebut terkonfirmasi oleh hasil analisis penentuan komposisi asam lemak yang ditampilkan pada Tabel 2. Minyak biji kapuk pada penelitian ini, sesuai hasil analisis dengan KG-SM, didominasi oleh asam lemak tak jenuh rantai panjang, yaitu asam oleat (C18:1 cis) sebanyak 47,23\% dan asam linoleat (C18:2) sebanyak 8,22\%. Penelitian lain melaporkan hasil berbeda, namun tetap menyatakan bahwa minyak biji kapuk didominasi oleh asam lemak tak jenuh. Minyak biji kapuk dilaporkan tersusun dari $22,3 \%$ asam palmitat $(\mathrm{C} 16: 0)$ dan 3,36\% asam stearat (C18:0) sebagai asam lemak jenuh, serta 70,71\% asam linoleate sebagai asam lemak tak jenuh [15]. Perbedaan jenis dan komposisi asam lemak dari minyak nabati merupakan fakta yang biasa terjadi sebagai akibat perbedaan iklim, varietas tanaman, masa panen, dan metode penyiapan [16].

Tabel 2. Tiga Jenis Asam Lemak Utama Penyusun Minyak Biji Kapuk Setelah Tahap Penghilangan Gum

\begin{tabular}{llc}
\hline \multicolumn{1}{c}{ Asam Lemak } & Jenis Asam Lemak & Kadar (\%) \\
\hline Asam palmitat (C16:0) & & 20,54 \\
Asam stearat (C18:0) & Jenuh & 4,88 \\
Asam lignoserat (C24:0) & & 3,39 \\
\hline Asam oleat (C18:1 cis) & & 47,23 \\
Asam linoleat (C18:2) & Tak jenuh & 8,22 \\
Asam palmitoleat (C16:1) & & 0,54 \\
\hline
\end{tabular}




\subsection{Karakteristik minyak biji kapuk setelah tahap ozonasi}

Tahap ozonasi terhadap minyak biji kapuk dimaksudkan untuk menyederhanakan struktur molekul dari minyak biji kapuk dengan cara memperpendek rantai karbon dari asam lemak penyusun struktur molekul trigliserida melalui pemutusan rantai karbon pada ikatan rangkap dari asam lemak. Pemutusan ikatan rangkap tersebut akan dihasilkan trigliserida dengan rantai karbon asam lemak lebih pendek dan sejumlah asam lemak bebas. Oleh karena itu, salah satu ukuran keberhasilan dari tahap ozonasi terhadap minyak dapat ditinjau dari perubahan bilangan asam dari minyak. Semakin meningkat bilangan asam dari minyak setelah ozonasi menunjukkan tahap ozonasi dikatakan semakin berhasil dalam menyederhanakan struktur molekul dari minyak.

Tabel 3. Sifat Kimia Fisik Minyak Biji Kapuk Sebelum dan Setelah Tahap Ozonasi

\begin{tabular}{lcc}
\hline \multirow{2}{*}{ Parameter } & \multicolumn{2}{c}{ Nilai } \\
\cline { 2 - 3 } & Sebelum & Setelah \\
\hline Bilangan asam $(\mathrm{mg} \mathrm{KOH} / \mathrm{g}$ minyak) & 17,11 & 21,86 \\
Bilangan penyabunan $(\mathrm{mg} \mathrm{KOH} / \mathrm{g}$ minyak) & 78,84 & 99,59 \\
Densitas pada $40^{\circ} \mathrm{C}\left(\mathrm{kg} / \mathrm{m}^{3}\right)$ & 907,5 & 906,0 \\
\hline
\end{tabular}

Ozonasi terhadap minyak biji kapuk dilakukan selama 120 menit. Karakteristik kimia fisik dan komposisi asam lemak dari minyak setelah tahap penyerhanaan struktur molekul ini ditampilkan pada Tabel 3 dan dan Tabel 4. Bilangan asam pada minyak biji kapuk meningkat dari 17,11 mg KOH/g minyak (sebelum ozonasi) menjadi 21,86 mg KOH/g minyak. Bilangan asam menunjukkan kandungan asam lemak bebas di dalam minyak. Semakin meningkatnya bilangan asam dari minyak biji kapuk setelah tahap ozonasi mengindikasikan bahwa telah terjadi proses pemutusan ikatan rangkap pada asam lemak penyusun minyak biji kapuk. Semakin besar bilangan asam, maka kadar asam lemak bebas dalam minyak semakin meningkat [17]. Hasil penelitian ini bersesuaian dengan penelitian Sadowska dkk. [9]. Pada penelitian tersebut, bilangan asam dari minyak zaitun mengalami peningkatan menjadi $1,7 \mathrm{mg} \mathrm{NaOH} / \mathrm{g}$ setelah minyak diozonasi selama 7 jam, jika dibandingan dengan tanpa diozonasi $(0,3 \mathrm{mg} \mathrm{NaOH} / \mathrm{g})$. Sedangkan ozonasi terhadap minyak kedelai selama 7 jam meningkatkan bilangan asam dari 0,3 menjadi $1,9 \mathrm{mg} \mathrm{NaOH} / \mathrm{g}$.

Tabel 4. Jenis dan Komposisi Utama Asam Lemak dari Minyak Biji Kapuk Setelah Ozonasi

\begin{tabular}{lcc}
\multicolumn{1}{c}{ Asam Lemak } & Jenis Asam Lemak & Kadar (\%) \\
\hline Asam palmitat (C16:0) & & 19,42 \\
Asam stearat (C18:0) & Jenuh & 5,30 \\
Asam arakidat (C20:0) & & 3,17 \\
\hline Asam linoleat (C18:2) & & 32,60 \\
Asam oleat (C18:1 cis) & Tak jenuh & 12,38 \\
Asam palmitoleat (C16:1) & & 0,43 \\
\hline
\end{tabular}

Peningkatan bilangan penyabunan minyak biji kapuk setelah tahap ozonasi dari 78,84 menjadi 99,59 mg KOH/g mengindikasikan struktur molekul trigliserida dari 
minyak semakin sederhana sebagai akibat terputusnya ikatan rangkap pada asam lemak selama ozonasi. Pemutusan ikatan rangkap tersebut, terutama pada asam lemak yang mengandung polyunsaturated, mengakibatkan penurunan densitas dari minyak [14].

Hasil analisis komposisi asam lemak pada minyak biji kapuk seperti ditampilkan pada Tabel 4 menunjukkan bahwa tahap ozonasi terhadap minyak biji kapuk mengakibatkan perubahan komposisi asam lemak. Secara akumulasi, minyak biji kapuk setelah ozonasi mengalami penurunan kadar asam lemak tak jenuh dimana asam oleat (C18:1 cis) merupakan asam lemak tak jenuh yang paling dominan mengalami perubahan struktur molekul sehingga kadarnya mengalami penurunan paling besar setelah diozonasi. Kadar asam oleat pada minyak biji kapuk setelah ozonasi menjadi $12,38 \%$ dari yang sebelumnya sebesar $47,23 \%$.

\subsection{Rendemen dan karakteristik kimia fisik biodiesel}

Pada penelitian ini biodiesel atau metil ester disintesis dalam 2 tahap proses, yaitu esterifikasi dan transestersifikasi. Esterifikasi dilakukan untuk mengkonversi asam lemak bebas yang terdapat pada minyak biji kapuk setelah mengalami tahap penyederhanaan struktur molekul minyak, menjadi biodiesel. Sedangkan tahap transesterifikasi dilaksanakan untuk mengkonversi trigliserida pada minyak biji kapuk menjadi biodiesel. Pada kedua tahap sintesis biodiesel tersebut digunakan sistem reaksi katalitik dengan perbedaan signifikan, dimana pada esterifikasi diterapkan reaksi katalitik homogen dengan katalis asam, dan pada transesterikasi diterapkan reaksi katalitik heterogen basa. Untuk keperluan pencampuran antar bahan reaksi (minyak, metanol, dan katalis), pada kedua tahap sintesis biodiesel tersebut digunakan bantuan gelombang ultrasonik dengan frekuensi $35 \mathrm{kHz}$ masing-masing selama 30 detik. Pengaruh waktu transesterifikasi minyak biji kapuk terozonasi terhadap rendemen biodiesel ditampilkan pada Gambar 2.

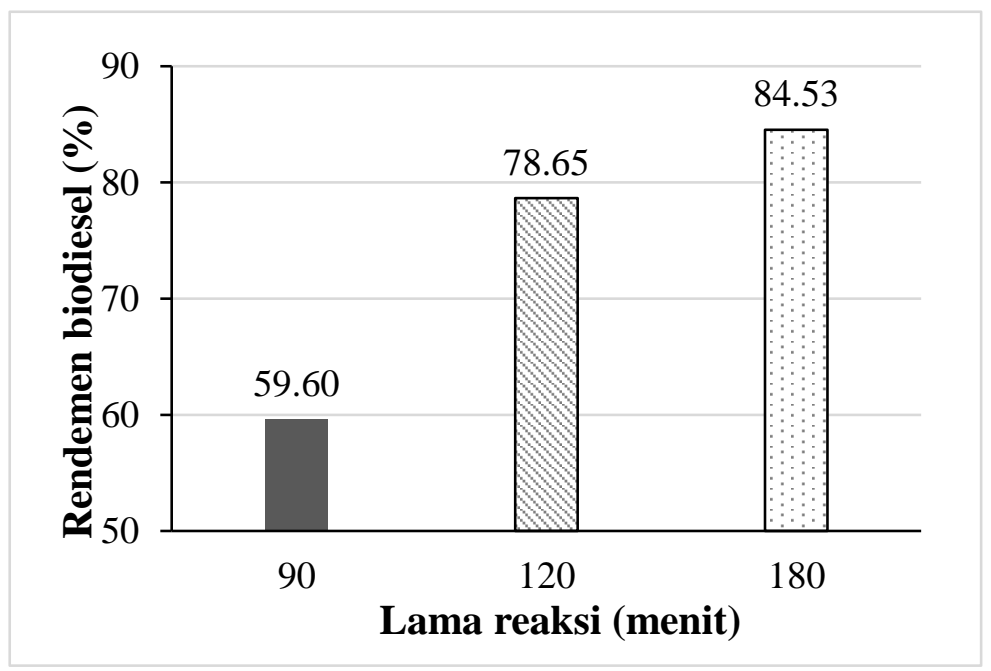

Gambar 2. Pengaruh Lama Reaksi Transesterifikasi Minyak Biji Kapuk Terozonasi terhadap Rendemen Biodiesel

Hasil penelitian pada Gambar 2 menunjukkan bahwa semakin lama transesterifikasi dilakukan, rendemen biodiesel yang diperoleh semakin banyak. Pada reaksi dengan model operasi partaian atau batch, derajat konversi reaktan menjadi produk 
berbanding lurus terhadap lama waktu reaksi [18], sehingga rendemen produk reaksi menjadi semakin tinggi seiring dengan lamanya waktu reaksi. Selain itu, hubungan antara waktu reaksi dengan rendemen biodiesel tersebut menunjukkan bahwa reaksi berlangsung ke satu arah, atau belum mencapai kondisi kesetimbangan, yaitu ke arah pembentukan produk (biodiesel).

Hasil penelitian juga menunjukkan bahwa lama reaksi pada tahap transesterifikasi berpengaruh terhadap karakteristik kimia fisik dari biodiesel yang dihasilkan. Tabel 5 menampilkan karakteristik biodiesel minyak biji kapuk dari variasi waktu transesterifikasi dan perbandingannya dengan Standar Biodiesel [19]. Lama waktu transesterifikasi tidak memberikan hubungan yang konsisten terhadap karakteristik kimia fisik biodiesel yang dihasilkan. Penurunan secara signifikan nilai bilangan asam dari sebelum tahap esterifikasi dan transesterifikasi sebesar 21,86 mg KOH/g minyak menjadi $0,35-0,46 \mathrm{mg} \mathrm{KOH} / \mathrm{g}$ minyak setelah transesterikasi menunjukkan bahwa hampir semua asam lemak bebas yang terdapat pada minyak biji kapuk terozonasi telah berhasil dikonversi menjadi biodiesel, khususnya pada saat tahap esterifikasi. Titik nyala biodiesel dari semua variasi waktu reaksi telah memenuhi Standar Biodiesel, yaitu di atas $100{ }^{\circ} \mathrm{C}$. Titik nyala pada biodiesel umumnya dikaitkan dengan tingkat kemurnian biodiesel dari keberadaan pengotor berupa metanol, karena metanol memiliki titik nyala jauh di bawah $\left(12,5{ }^{\circ} \mathrm{C}\right)$ daripada titik nyala metil ester atau biodiesel murni [20]. Oleh karena itu, semakin banyak kadar metanol dalam biodiesel mengakibatkan titik nyala biodiesel semakin rendah dari yang seharusnya, demikian sebaliknya.

Tabel 5. Perbandingan Karakteristik Kimia Fisik Biodiesel dari Variasi Waktu Lama Transesterifikasi terhadap Minyak Biji Kapuk Terozonasi

\begin{tabular}{lcccc}
\hline \multirow{2}{*}{\multicolumn{1}{c}{ Parameter }} & \multicolumn{3}{c}{ Biodiesel (menit) } & Standar \\
\cline { 2 - 4 } & $\mathbf{9 0}$ & $\mathbf{1 2 0}$ & $\mathbf{1 8 0}$ & Biodiesel \\
\hline Bilangan asam (mg KOH/g minyak) & 0,46 & 0,35 & 0,38 & Maks. 0,5 \\
Bilangan penyabunan & 119,99 & 112,58 & 122,95 & - \\
$(\mathrm{mg} \mathrm{KOH} / \mathrm{g}$ minyak) & 897 & 899 & 898 & $850-890$ \\
Densitas pada $40{ }^{\circ} \mathrm{C}\left(\mathrm{kg} / \mathrm{m}^{3}\right)$ & 20,2 & 16,6 & 15,8 & $2,3-6,0$ \\
Viskositas pada $40{ }^{\circ} \mathrm{C}\left(\mathrm{mm}^{2} / \mathrm{s}\right)$ & 125 & 116 & 121 & Min. 100 \\
Titik nyala $\left({ }^{\circ} \mathrm{C}\right)$ & & &
\end{tabular}

Bilangan penyabunan biodiesel dari berbagai variasi waktu transesetrifikasi sebesesar 112,58 - 122,95 mg KOH/g minyak. Nilai bilangan penyabunan dari biodiesel tersebut sudah cukup signifikan terjadi kenaikan jika dibandingkan dengan minyak biji kapuk sebelum mengalami tahap esterifikasi dan transesetrifikasi, yaitu sebesar $99,59 \mathrm{mg} \mathrm{KOH} / \mathrm{g}$ minyak. Kenaikan bilangan penyabunan tersebut mengindikasikan bahwa sejumlah tertentu trigliserida dari minyak biji kapuk telah terkonversi menjadi metil ester (biodiesel) pada tahap transesterifikasi, namun dengan tingkat konversi belum mencapai kondisi optimum. Hal tersebut terkonfirmasi dari nilai viskositas biodiesel dari semua variasi waktu transesterifikasi yang masih lebih tinggi dari Standar Biodiesel. 


\section{Kesimpulan}

Perlakuan ozonasi dan penggunaan gelombang ultrasonik pada sintesis biodiesel dari minyak biji kapuk berpengaruh terhadap nilai rendemen dan karakteristik kimia fisik biodiesel yang dihasilkan. Ozonasi terhadap minyak biji kapuk mengakibatkan struktur molekul trigliserida dari minyak menjadi lebih sederhana dengan diindikasikan oleh kenaikan bilangan asam dan bilangan penyabunan. Hasil tersebut dikonfirmasi oleh penurunan kadar asam lemak rantai panjang jenis asam oleat.

Asam lemak bebas dari minyak biji kapuk sebagai salah satu produk dari tahap ozonasi telah relatif berhasil dikonversi secara komplit menjadi biodiesel pada tahap esterifikasi. Sedangkan trigliserida dari minyak biji kapuk masih relatif belum terkonversi secara lengkap menjadi biodiesel pada tahap transesterifikasi. Hal tersebut ditunjukkan oleh parameter viskositas dari biodiesel yang belum sesuai dengan Standar Biodiesel dan terkonfirmasi oleh nilai bilangan penyabunan dari biodiesel.

\section{Daftar Pustaka}

1. A. Hayyan, M.Z. Alam, M.E.S. Mirghani, N.A. Kabbashi, I.N.M. Hakimi, Y.M. Siran, S. Tahiruddin, Production of biodiesel from sludge palm oil by esterification process, Journal of Energy and Power Engineering, Vol. 4 No. 1 (2010), p. 11-17.

2. V.J. Gerpen, B. Shanks, R. Pruszko, D. Clements, G. Knothe, Biodiesel Production Technology, National Renewable Energy Laboratory (2004), US Department of Energy, Colorado, USA.

3. G.B. Nkouam, G.A. Adjoh, C.B. Tchankou Leudeu, C. Kouebou, C. Tchiegang, C. Kapseu, Physico-chemical properties of fruits, seed and oil of kapok (Ceiba pentandra Gaertn.) tree of different provenances from the Northern Part of Cameroon, International Journal of Agriculture Innovations and Research, Vol. 6 No. 2 (2017), p. 275-278.

4. P.S. Montcho, L. Tchiakpe, G. Nonviho, F.T.D. Bothon, et al. Fatty acid profile and quality parameters of Ceiba pentandra (L.) seed oil: a potential source of biodiesel, Journal of Petroleum Technology and Alternative Fuels, Vol. 9 No. 3 (2018), p. 14-19.

5. S. Vedharaj, R. Vallinayagam, W.M. Yang, S.K. Chou, K.J.E. Chua, P.S. Lee, Experimental investigation of kapok (Ceiba pentandra) oil biodiesel as an alternate fuel for diesel engine, Energy Conversion and Management, Vol. 75 (2013), p. 773-779.

6. Haryono, A. Marliani, Analisis mutu biosolar pada variasi formulasi blending biodiesel dari minyak biji kapuk dengan minyak solar, Eksergi, Vol. 11 No. 2 (2014), p. 25-30.

7. G. Knothe, J.V. Gerpen, J. Krahl, The Biodiesel Handbook, AOCS Press (2005), Champaign-Illinois, USA.

8. F. Ganduglia, Handbook on Biofuels, ARPEL's Refining Committee (2009), Montevideo, Uruguay.

9. J. Sadowska, B. Johansson, E. Johannessen, R. Friman, L. Broniarz-Press, J.B. Rosenholm, Characterization of ozonated vegetable oils by spectroscopic and 
chromatographic methods, Chemistry and Physics of Lipids, Vol. 151 (2008), 85-91.

10. Biodiesel TechNotes, Faster biodiesel processing with ultrasound-assisted reactors, Department of Biological and Agricultural Engineering (2012), University of Idaho, Moscow.

11. S. Yan, M. Kim, S. Mohan, S.O. Salley, K.Y. Simon, Effects of preparative parameters on the structure and performance of Ca-La metal oxide catalysts for oil transesterification, National Biofuels Energy Laboratory (2010), Wayne State University, USA.

12. A.S. Badday, A.Z. Abdullah, K.T. Lee, M. Khayoon, Intensification of biodiesel production via ultrasonic-assisted process: a critical review on fundamentals and recent development, Renewable and Sustainable Energy Reviews, Vol. 16 (2012), p. 4574-4587.

13. S. Larpkiattaworn, J. Chalermchai, T. Rattikan, T. Siriporn, Ultrasonic on transesterification reaction for biodiesel production, Biomass Asia Workshop (November 2010), Jakarta, Indonesia.

14. S.D. Sanford, J.M. White, P.S. Shah, C. Wee, M.A. Valverde, G.R. Meier, Technical report: Feedstock and biodiesel characteristics report, Iowa Renewable Energy Group Inc. (2009), p. 1-136.

15. E.M.M. Putri, M. Rachimoellah, N. Santoso, F. Pradana, Biodiesel production from kapok seed oil (Ceiba Pentandra) through the transesterification process by using $\mathrm{CaO}$ as catalyst, Global Journal of Researches in Engineering, Vol. 12 No. 2(2012), p. 1-5.

16. B.R. Moser, Biodiesel production, properties, and feedstocks, Plant, Vol. 5 (2009), p. 229-266. doi: 10.1007/s11627-009-9204-z

17. D.T. Almeida, T.V. deViana, M.M. Costa, C. deS. Silva, S. Feitosa, Effects of different storage conditions on the oxidative stability of crude and refined palm oil, olein and stearin (Elaeis guineensis), Food Science and Technology, Vol. 39 No. 1(2019), p. 211-217.

18. P. Harriott, Chemical reactor design, 1st Edition, Marcel Dekker, Inc. (2003), New York, p. 13-15.

19. Badan Standardisasi Nasional, SNI 7182-2015, Standar Nasional Indonesia Biodiesel (2015), Jakarta.

20. Alternative Fuels Data Center: Fuel properties comparison, Department of Energi (2021), USA. Tersedia di:

https://afdc.energy.gov/files/u/publication/fuel_comparison_chart.pdf

[Diakses tanggal 16 Desember 2021] 